\title{
PROMOTION OF CHILDREN'S COOPERATION AND PHYSICAL DEVELOPMENT IN THE PRE-SCHOOL OUTDOOR SPACE
}

\author{
Agita Ābele', Agrita Tauriṇa², Tija Zīriṇa², Dace Rutkovska ${ }^{3}$ \\ ${ }^{1}$ Latvian Academy of Sport Education, Latvia \\ ${ }^{2}$ University of Latvia, Latvia \\ ${ }^{3}$ Riga $275^{\text {th }}$ preschool educational establishment "Austrina" Latvia
}

\begin{abstract}
In order to follow advice of epidemiologists on measures for limiting the spread of COVID-19 in Latvia, employees of pre-school educational establishments are increasingly paying attention to ensuring the availability of a safe outdoor setting. Children's transferrable skills and a healthy lifestyle are a topical matter within educational reform and the competency approach in pre-school. Observations by teachers indicate that children's cooperation skills at the age of five and six years are insufficiently developed, and adults struggle to promote them, especially in the outdoor environment where it's often associated with new challenges, and the work of organizing activities is more involved. Teachers have difficulties ensuring the availability of materials necessary for children's cooperation and physical development and directing attention towards promoting dialogic speech and cognitive interests. To purposefully promote children's cooperation in various outdoors activities, improve dialogic speech, and make examples of pedagogical work experiences more widely available to teachers, it would be important to promote the points recognized in the project "Teaching learning spaces competence from early childhood education" [TELESPA] (20181-RO01_KA201_049545, PVS_ID_3910), which was done in collaboration between Riga $275^{\text {th }}$ pre-school "Austrina" and the EU education, learning, youth and sports program ERASMUS. We discovered during research that children of the oldest pre-school age group tend to be interested in determining characteristic traits of objects, looking for causality, and doing practical work. However, their abilities to come to an agreement, justify intentions, think critically, and ask questions are insufficiently developed. We have noticed that good pronunciation of sounds, learning of grammar, and broadening of vocabulary improve children's relationships with peers and grown-ups, they also make it easier to enact cooperation and various physical education activities outdoors. Purposefully made sensory gardens in the pre-school outdoor setting, available thanks to the EU education, learning, youth and sports program ERASMUS+ project "TELESPA" achieving its goals, provide an opportunity to evaluate children's cooperation and opportunities for physical development
\end{abstract}


promotion, and determine teachers' experience in evaluating children's achievements. It is important to find out the given children's needs, interests, and abilities during the planning stage of pedagogical work - points recognized during this project's trial runs should help with this task.

Keywords: cooperation, older pre-school child, physical development, pre-school outdoor environment, transferrable skills.

\section{Introduction}

Today, more and more educators are being called on to implement learning outside - in school courtyards or gardens, parks, forests, outdoor classes, and they are encouraging children to explore, creatively express and develop their ability to judge, but most importantly to use nature as a learning resource with authentic and meaningful content (Andrušaite \& Langenfelde, 2010). A child learns the desired attitude towards their surroundings from adults. The child watches their behaviour, their reaction, listening carefully to their opinions. The adult's attitude becomes an example for imitation. Nowadays, increasingly more pedagogical activity is taking place outdoors, both with teachers and with parents, which creates the opportunity and necessity to learn from new and previously unexperienced locations and situations. Therefore, the choice of adults to spend more time with children in the outdoor environment and enjoy the opportunity to be in nature is so important. Interaction with the natural world offers meaningful experiences for pre-school age children. Playing outdoors provides good conditions for children's social, emotional, spiritual, physical, and cognitive development (Larimore, 2018). Despite many positive aspects, there are some difficulties. Pre-school teachers have difficulties ensuring the availability of materials necessary for children's cooperation and physical development, and directing attention towards promoting dialogic speech and cognitive interests. That's a reason to purposefully promote children's cooperation in various outdoors activities, improve dialogic speech, and make examples of pedagogical work experiences more widely available to teachers.

Outdoor pedagogy is a learning method where a child, supervised by an educator, gains knowledge and common experiences in nature. It is not only knowledge of nature that can be learned from the outdoor pedagogy, but other topics also. It opens up the possibility of communication - of creating a dialogue. Children of pre-school age are eager to find out the relationship between things, phenomena and events, they are eager to find out how things works and affect each other. They are happy to ask one "why" after another and are happy to gain undivided attention. Several things of interest are being studied insistently and playfully repeated with 
joy. Such childhood behaviour should not be seen as annoying to the adult, but as a child's natural need. Children ask adults a lot of questions. They're waiting for an answer, they're trying to figure out, they're expressing doubt. Enduring an inquisitive child's attitude towards the world and nature depends on whether the adult promotes it positively or suppresses a child's initiative with perfunctory attitudes (Priede \& Freiberga, 2007).

The aim of the research is to analyse the provision of outdoor environments for children's cooperation and physical development, outline suggestions for teachers and parents that would help with promoting physical development and transferrable skills - to encourage cooperation.

\section{Methodology}

The research includes a theoretical method - analysis of scientific literature, and empirical methods. Three different survey forms were used in the study: Herms, Clifford, and Clyer environment assessment form for early childhood learning environments "Early Childhood Environment Rating Scale ${ }^{\circledR}$, Revised (ECERS-R ${ }^{\mathrm{TM}}$ )" (Herms, Clifford, Cryer, 1998), PK2 (PreKindergarten, age level 2-3 years), Teacher Roles Observation Schedule (Alford, 2011) and an interview of pre-school teachers. An ECERS-R assessment was made in 15 pre-school classrooms and reflects on the environment's suitability to outdoor activities and interaction between children and staff. In the PK2 assessment, observations were made on teachers' classroom leadership methods and interactions with students. Teachers were observed with reference to interactions with students; the instructional setting in which the observed behaviour occurred; whether the instruction was of a direct, seatwork, or learner entered orientation; the nature of the interaction; the purpose of the interaction; instructional practices; and language used. In the teachers' interviews, 20 pre-school teachers answered questions about their experiences with outdoor education and encouraging cooperation skills among children. The teachers were asked to answer a semi-structured questionnaire. The data was analysed quantitatively and qualitatively. In order to respect the confidentiality of the study participants, it was not necessary to provide the name and surname of the study participants, as well as any other personal identification data, when filling in the questionnaire. Teachers were interviewed by the author at their preschool in a room away from the children and at a time convenient to them.

\section{Results}

The ECERS-R assessment shows that there is enough space for outdoor play and basic equipment for outdoor play in assessed pre-schools (Figure 1). 
Section 8.1.1 is assessed differently, (very little gross motor equipment used for play) because, as the survey data showed, pre-school teachers avoid organizing these activities - 17 out of 20 teachers avoided this activity. They want this to be done by a sports teacher who works as a pre-school teacher with a specific group of children once a week. On other days of the week, it is the responsibility of the group teachers to carry out this work and receive advice from the sports teacher. The space for outdoor play and equipment is the base on which teachers plan their outdoor lessons and activities. And as it can be seen in teachers' surveys (ECERS), teachers regularly plan and organize outdoor lessons and activities for children.

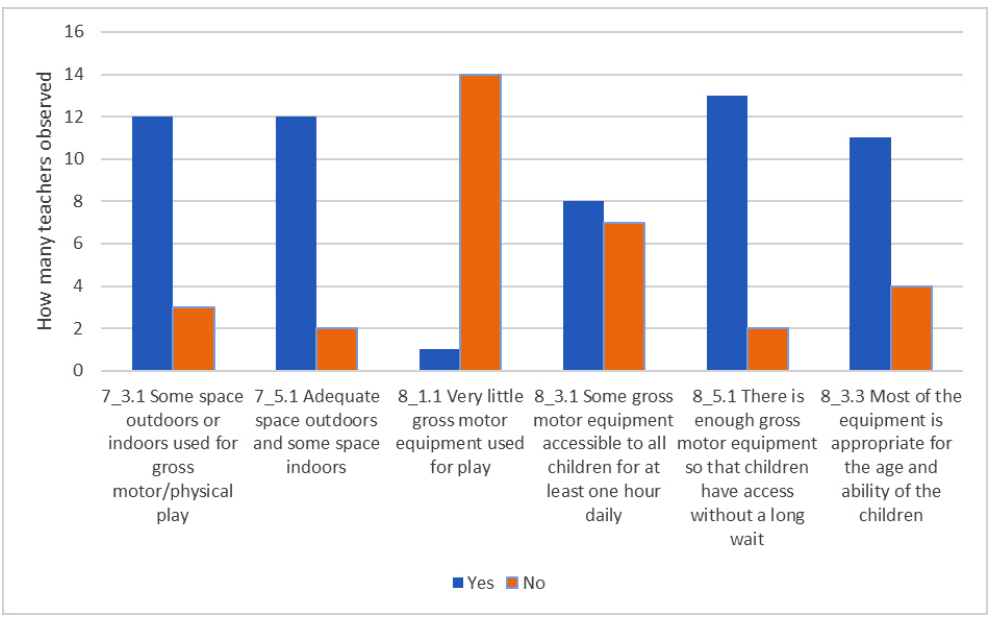

Figure 1. Adequate space and equipment for outdoor activities (in points)

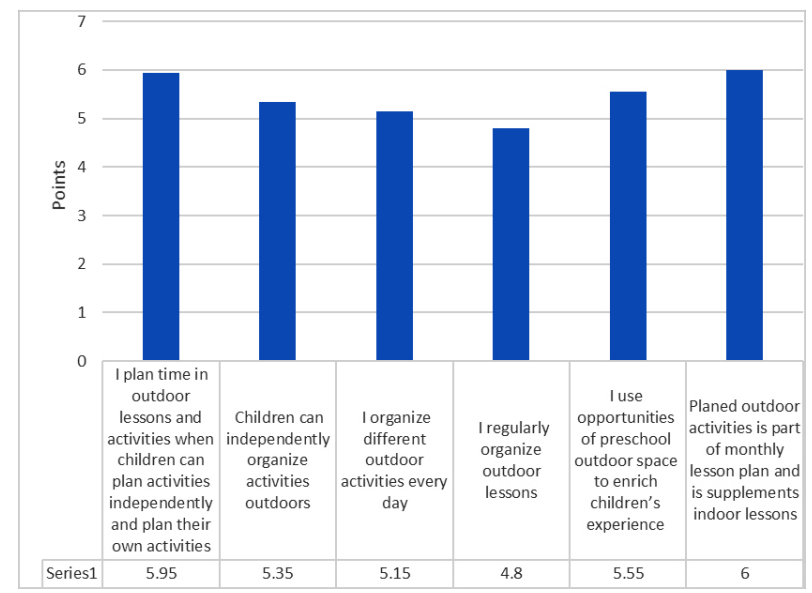

Figure 2. Teachers' opinions on outdoor lesson planning (in points) 
Teachers were asked if they fully agree with the statement (6 points), agree with the statement (5 points), mostly agree with the statement (4 points) (Figure 2).

From 20 teachers interviewed, most teachers fully agree or agree with statements about outdoor lesson planning. That shows that if teachers have adequate outdoor space, they will use the outdoor space for lesson plans. In planning outdoor lessons, as stated in the aim of the study, it is important to encourage children's cooperative skills.

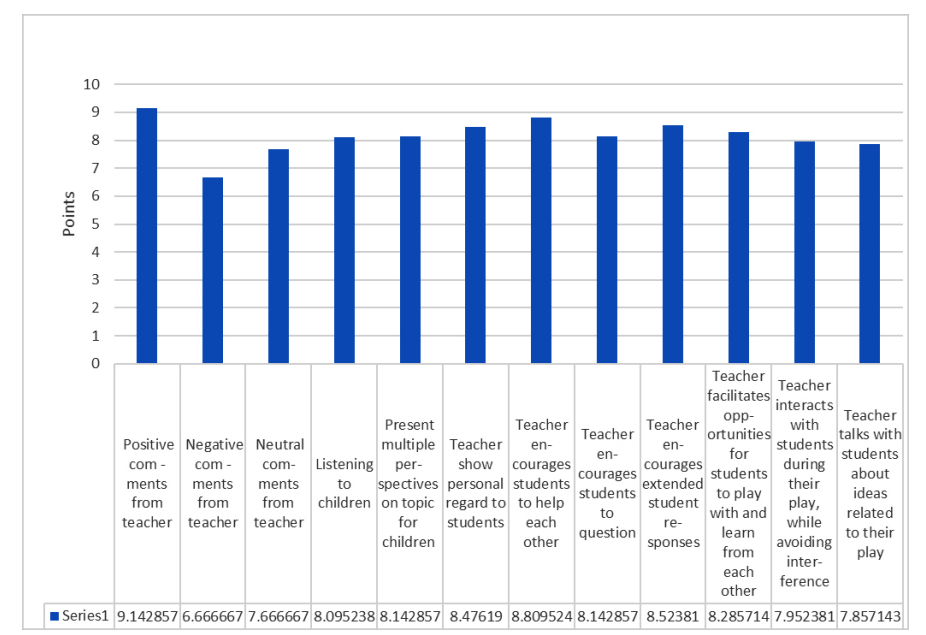

Figure 3. PK2 Teacher Roles Observation Schedule survey

The PK2 teachers survey distinguishes several aspects of a teacher's behaviour that can influence children's language development, problem solving and cooperation skills (Figure 3). The observations of lessons rated teachers' behaviours on a scale from 1 to 10. The highest results are obtained in the section "Nature of interaction. Positive commenting" which received 9 points. There is a similar assessment in the sections "Purpose of interaction encourage students to help each other" and "Purpose of interaction encourage extended students responses. Teachers generally gave high scores for all criteria, which means teachers pay attention to them in their daily work.

The greatest attention and, consequently, the highest marks in self-assessment are given by teachers in the following sections "I plan time in outdoor lessons and activities when children can plan activities independently and plan their own activities" "I teach children to be polite to other speakers" "I offer personal examples to children, how to listen to each other, by listening to children with undivided attention" "When organizing outdoor lessons I plan activities that promote children's independence and cooperation skills" (Figure 4). 


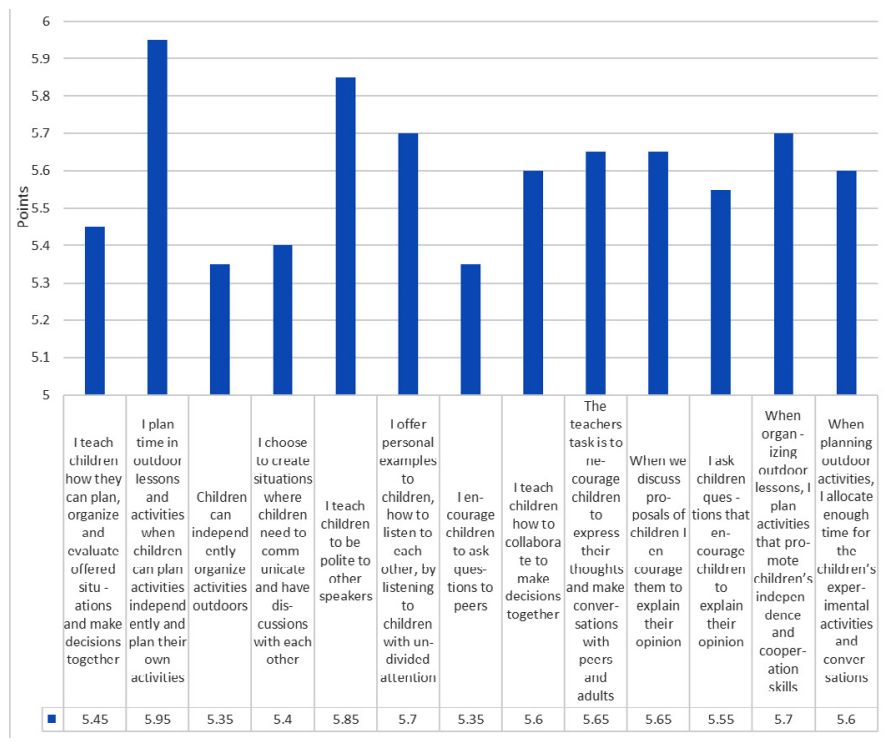

Figure 4. Teachers opinions on promoting childrens interaction

In turn, the lowest results are in the following sections "Children can independently organize activities outdoors" "I choose to create situations where children need to communicate and make discussions with each other" "I encourage children to ask questions to peers". As a good example for ensuring the high-quality use of the outdoor environment, 2 sensory gardens were created, with children also participating in their creation. Parents were provided with information about the cooperation between employees and parents in the creation of sensory gardens.

\section{Discussion}

Development of social skills and cultural knowledge in the outdoor environment naturally prompt children to contact and cooperate with others - children, parents and educators. They promote cooperation and communication skills. Children learn about the surrounding society and our culture through walks. Emotional development - being in an outdoor environment gives children a variety of sensory experiences. It is a big, spacious, unlimited "room" for experiments, movement and play. It is food for our soul (Robertson, Miller, 2020). Within Early Learning and Childcare (ELC) establishments, it is expected that settings will provide a balance of provision between the indoor and outdoor spaces. Yet often, it is challenging for practitioners within the constraints of their work indoors to come up with a sufficient range of ideas and ways of achieving them. Outside there is space and height to experiment with scale and far more stimuli 
than indoors (e. g., sounds). There is room to move and use the whole body. We can make the most of the outdoor space for experiences which couldn't happen inside. In the natural world, we can tune in to the sounds, rhythms and tunes provided by the movement and noise created by wind, plants, animals and the landscape. Think of the waves crashing on the shore, or the movement of pebbles being pulled back into the sea by waves and then re-deposited time and time again on a rocky shore. There is atimelessness to natural soundscapes. It is food for our souls (Robertson \& Miller, 2020). Jorgensen indicates that outdoor learning spaces offer new experiences, facilitate children's curiosity and expands consciousness of the environment. This is a natural way of raising interest in their surroundings, and at the same time, facilitates children's physical and cognitive development (Jorgensen, 2016).

When a child talks, he/she develops his/her dialogue skills, wording his/her needs in questions and answers, his/her thoughts, as well as improving collaborative communication with a partner. It is important to acknowledge that dialogue is the most natural form of the child's conversation. There needs to be understanding between children in the form of joint talks (Dzintere, Stangaine, Augstkalne, 2014). If an adult does not show a willingness to answer a child's questions, interest diminishes and gets replaced by indifference. Luckily, children's interest and curiosity levels in the pre-school age are typically very high and resilient (Grava, 2012). An outdoor learning space is an integral part of the total learning environment. It is not only a playground. It is a place where children's learning is enhanced by the acquisition of knowledge and skills through experiences in a natural environment (Slater \& Boulton, 2018). It is also important to consider that for successfully ensuring the physiological functions of a child of pre-school age, it is recommended that they spend at least 3-4 hours each day in an outdoor environment.

Outdoor learning space is a place where children are in close interaction with a teacher. Tonge and colleagues (2019) stress the significant influence on quality educator and child interactions in outdoor environments in their research. A teacher's knowledge about the benefits of an outdoor learning space is of crucial importance, and they provide the best opportunities for children's learning, development, health, and wellbeing (Tonge et al., 2019). The problem in the way of a successful implementation of an outdoor learning space sometimes is the teachers' preconceptions about difficulties in organizing an outdoor learning environment. These barriers can be reduced by teachers' professional development in outdoor education, and that would be the best solution to help with providing children positive experiences in making use of natural settings (Ernst, 2014). Of course, the role of parents is very big too. Parents' involvement and positive attitude 
are important to successful outdoor learning. Some parents are concerned about children's safety and clothing when going outdoors. By listening to parents' concerns it is possible to find the best solutions to providing outdoor experiences for children of all ages (Adams, 2013).

The study clearly showed that in addition to the positive factors, there are also negative ones. According to the results from Simge (2016), although early childhood educators have positive thoughts and attitudes regarding the importance of outdoor activities on children's development and learning, they indicated that some factors, such as insufficient physical conditions, lack of safety at school gardens, crowded classes, inappropriate weather conditions, and lack of parental permission prevent them to practice such activities outdoors (Simge, 2016).

Amini (2015) notes that outdoor learning is an attempt to assist learners in achieving learning objectives, avoid boredom and the mindset that learning must be done inside the class, and that students who obtain outdoor learning will generally behave better than those who do not experience it (Amini, 2015). Practice shows that nature provides stimulation, relaxation and restoration. An outdoor learning space promotes children's physical and mental development. Children are interested in being involved in nature-related activities and projects, where learning is provided in all domains - physical, cognitive, social, and emotional (Torquaty et al., 2010).

\section{Conclusions}

- The experience of the TELESPA project confirms the possibilities of a purposefully designed pre-school outdoor environment, in which it is possible to assess children's cooperation and opportunities to promote physical development, which is also determined by a teacher's experience in assessing the children's achievements.

- It is important to find out the given child's needs, interests, and abilities during the planning stage of pedagogical work - points recognized during this project's trial runs should help with the task.

- During outdoor activities, teachers should: observe children, support children's activities, find out children's opinions, invite children to explain their position and desired action, invite to choose game partners and communicate with them, invite to share their viewpoints, interests and emotions.

- In order to implement outdoor pedagogy more widely, parental support and interest is needed to provide children with weather-appropriate clothing, as well as greater parental understanding of the importance of the outdoor environment for the child's development. 


\section{References}

Adams, J. A. (2013). Nature - Based learning. Taking Infants and Toddlers Outside. Young Children, July, 94-96.

Alford, B. L. (2011). Systematic Classroom Observation of the Quality of Teacher Behaviors and Student Engagement in Ethnically Diverse Pre-Kindergarten Through Second-grade Classrooms. [Doctoral Dissertation, Texas A\&M University]. http://oaktrust.library.tamu.edu/ handle/1969.1/ETD-TAMU-2011-05-9226

Amini, R. (2015). Outdoor based environmental education learning and it's effect in caring attitude toward environment. Indonesian Journal of Science Education. https:// journal.unnes.ac.id/nju/index.php/jpii/article/view/3500

Andrušaite, A., Langenfelde, M. (2010). Kas ir āra klase un kāda ir tās loma vides izglītỉbāa? Rokasgrāmata. [What is an outdoor classroom and what is its role in environmental education? Handbook.] Sigulda. https://www.daba.gov.lv/upload/File/Publikacijas/ ROKASGR_Ara_klase.pdf

Dzintere, D., Stangaine, I., Augstkalne D. (2014). Bērna komunikativās kompetences attistiba. [Development on the child's communicative competence]. Rìga, RaKa.

Ernst, J. (2014). Early childhood educators' use of natural outdoor settings as learning environments: an exploratory study of beliefs, practices, and barriers. Environmental Education Research, 20(6), 735-752. http://dx.doi.org/10.1080/13504622.2013.833596

Grava, J. (2012). Pirmsskolas vecuma bērna pētnieciskā darbība pieaugušo radītajā vidē. [Research activity of a preschool child in the environment created by adults]. Society. Integration. Education (pp. 57-64) Rēzekne, RA, http://journals.ru.lv/index.php/ SIE/article/view/19/19

Herms T., Clifford R. M., Cryer D. (1998) Early Childhood Environment Rating Scale. Columbia University, Teachers College Press.

Jorgensen, K. A. (2016). Bringing the jellyfish home: environmental consciousness and 'sense of wonder' in young children's encounters with natural landscapes and places. Environmental Education Research, 22(8), 1139-1157. http://dx.doi.org/10.1080/13504 622.2015.1068277

Larimore, R. A. (2018). Using Principles of Nature-Based Preschools to Transform Your Classroom. Young Children, November, 34-41.

Priede, L., Freiberga I. (2007). Bērns mācās izzināt pasauli. [A child learns to explore the world]. Rīga, SIA Izglītības Soḷi.

Robertson, J., Miller A. (2020). Experiencing Music Outside. UK, Creative Star Learning. https://hub.careinspectorate.com/media/4051/ey-outdoor-music.pdf

Simge, Y. (2016). Outdoor Environment and Outdoor Activities in Early Childhoods Education. Mersin University Journal of the Faculty of Education, 12(1): 423-437. https:// dergipark.org.tr/tr/pub/mersinefd/issue/17399/182108

Slater, G., \& Boulton, P. (2018). Re-Imagining Outdoor Spaces for Young Children. Bridging Research and Practice, March/April, 76-78.

Tonge, K. L., Jones, R. A., \& Okely, A. D. (2019). Quality Interactions in Early Childhood Education and Care Centre Outdoor Environments. Early Childhood Education Journal, 47, 31-41. https://doi.org/10.1007/s10643-018-0913-y

Torquaty, J., Gabriel, M. M., Jones-Branch, J., \& Leeper-Miller, J. (2010). A Natural Way to Nurture Children's Development and Learning. Young Children, November, 98-104. 